\title{
The Effect of Collaborative Learning Technique on Students' Reading Comprehension
}

\author{
Rahmi Putri ${ }^{1}$, M. Zaim², and Hamzah ${ }^{3}$ \\ ${ }^{1}$ Student of Graduate Program, Universitas Negeri Padang, Padang, Indonesia, $\triangle$ (e-mail) \\ rahmiputri70@yahoo.com \\ ${ }^{2}$ Universitas Negeri Padang, Padang, Indonesia, $\$ (e-mail)mzaim_unp@yahoo.com \\ ${ }^{3}$ Universitas Negeri Padang, Padang, Indonesia, $\triangle$ (e-mail)hamzahhs@yahoo.com
}

\begin{abstract}
This research was aimed at testing the effect of collaborative learning technique on students' reading comprehension and it was a kind of quasi-experimental research. The population of this research was the tenth grade of SMKN 1 Pariaman enrolled on 2018/2019 academic year.The samples were X TMI1 as experimental class and X TMI2 as control class. During the treatment, students in experimental class used collaborative learning technique, while students in control class used small group discussion technique.The reading test was used to collect the data of the research. The data were analyzed by using t-test for hypothesis testing. The analysis of the test result showed that the student of experimental class was higher than control class. The result shows that collaborative learning produced better reading comprehension ability of analytical exposition text of the students than small group discussion technique.
\end{abstract}

Keywords: Collaborative learning technique, reading comprehension

\section{INTRODUCTION}

Reading is an activity in learning English. According to Martin-Chang and Gould (2008), reading is a process of constructing meaning from written texts. It is a complex skill requiring the coordination of interrelated sources of information. Through reading, students can improve their own language and experience. They will get information and ideas which they need to know. Moreover, they will be able to know elements of foreign language and models of language use. To understand about the content of the text, there is an aspect that should be had by students, that is comprehension.

Pressley (2000) states that reading comprehension refers to reading for meaning, understanding, and entertainment. It is the process of deriving the meaning of one word to another in a text. According to Hancock (1998), comprehension is the centre of reading. Good readers have a purpose for reading and use their experiences and background knowledge to make sense of the text. In short, reading comprehension can be concluded as the ability to find the stated or unstated writer's idea in the text. It also refers to the ability to connect between the words in a text, to understand the ideas and the relationships between ideas conveyed in a text.

There are various techniques that can be used in teaching reading. One of the techniques that could be used by the teacher is collaborative learning. Collaborative learning is an educational approach to teaching and learning that involves groups of learners working together to solve a problem, complete a task, or create a product (Roselli: 2016).

Laal and Ghodsi (2011) divide the benefits of collaborative learning into four majors, they are social benefit, psychological benefit, academic benefit, and alternate student and teacher assessment techniques. In social benefit, CL helps in developing social support systems for students, leads to build understanding of diversity among students and staff, builds a positive atmosphere to model and practice cooperation, and develops learning communities. Furthermore, in psychological benefit, CL increases students' self esteem, reduces anxiety, and develops positive attitudes towards teachers. In academic benefit, CL promotes critical thinking skills, involves students actively in the learning process, classroom results are improved, models appropriate student problem solving techniques, large lectures can be personalized, and CL is especially helpful in motivating students in specific curriculum. The last, CL can become an alternate student and teacher assessment techniques. Variety of assessment is utilized in collaborative teaching techniques.

According to Gokhale (1995), the term collaborative learning refers to to the method of teaching in which students at various performance levels work together in a group towards a common goal. Each member of the group must cooperate actively to achieve the objectives that have been determined in an activity so that the process of learning that is full of meaning. In addition, all the students are expected to engage with the activity done in the classroom. It provides students to learn and 
work together, share ideas and be responsible for the achievement of group and individual learning outcomes. In collaborative learning, students are divided into groups. Each group is given the task, such as a problem solving, by working with all members of the group. Each member is required to actively to solve the problem. Learning by this method is done in several meetings, depending on how difficult the problem is to be solved.

According to Brufee (1993), in learning processes that implement collaborative models, teachers share authority with students to use their knowledge, respect their colleagues and focus on high-level understanding. In collaborative learning models, a teacher is as a mediator. The teacher connects new information with students' experiences with learning in other fields, helps students determine what to do if students experience difficulties and helps them learn how to learn. Moreover, the teacher as a mediator has to adjust the level of student information and encourage students to maximize their ability to be responsible for the next learning process. As a mediator the teacher undergoes three roles, which function as facilitator, model and trainer.

\section{METHOD}

The population of this study was three classes of the grade $\mathrm{X}$ TMI at SMK N 1 Pariaman enrolled on 2018/2019 academic year. The decision to take the TMI classroom was based on the suggestion from the teacher. In addition, the researcher did the normality and homogeneity testing of the population from the result of students' reading test. The total of the population was 90 students.

The samples of this study were selected by using cluster random sampling technique. Three small papers (lottery) were picked, and class X TMI 2 was decided as experimental class and class X TMI 1 was decided as control class.

Table 1. The Number of Students in Each Class

\begin{tabular}{|c|c|c|}
\hline No & Class & Total \\
\hline 1 & X TMI 1 & 30 \\
\hline 2 & X TMI 2 & 30 \\
\hline 3 & X TMI 3 & 30 \\
\hline \multicolumn{2}{|c|}{ Total } & 90 \\
\hline
\end{tabular}

Source: SMKN 1 Pariaman academic year 2018/2019

The design of this study was a quasiexperimental research. Therefore, the researcher investigated the effect of collaborative writing as independent variable toward dependent variable namely students' reading comprehension. Clearly, there were two classroom techniques of teaching reading (collaborative learning technique and small group discussion technique).

In this study, reading test was the instrument. Reading test was aimed to collect the data of students' reading comprehension ability and it was used in post test.
The test material was consisted of certain materials that have been studied by the students. To measure students in reading comprehension, this research will use multiple choices. The test consists of seven reading texts and 40 questions. Each question has four options with one with possible right answer among the distracter. In addition, the researcher validated the test to the expert.

Table 2. The Indicators of Reading Test

\begin{tabular}{|c|c|c|}
\hline No. & $\begin{array}{l}\text { Indicators of } \\
\text { reading } \\
\text { comprehension }\end{array}$ & Sub indicators \\
\hline 1 & General information & $\begin{array}{ll}\text { - } & \text { Topic } \\
\text { - } & \text { Main idea }\end{array}$ \\
\hline 2 & Meaning of words & $\begin{array}{ll}\text { - } & \text { Reference } \\
\text { - } & \text { Synonym } \\
\text { - } & \text { Antonym }\end{array}$ \\
\hline 3 & Language features & $\begin{array}{ll}\text { - } & \text { Tenses } \\
\text { - } & \text { Verbs } \\
\text { - } & \text { Linking words }\end{array}$ \\
\hline
\end{tabular}

Adopted from Wegman (1985) and Blass (2007)

The data of this study were students' reading test scores. It was analyzed by using Liliefors test to see the normality. Then, to see homogeneity, the data was analyzed by using Variance (F) test. While, the hypotheses was analyzed by using t-test in excel program.

\section{RESULTS AND DISCUSSION}

Based on analysis, it was found that the mean score of the students reading test in experimental class was higher than the mean score of students reading test in control class, it is shown in the following table.

Table 3. Summary of Students' Reading Score from Experimental and Control Class.

\begin{tabular}{|c|c|c|c|c|}
\hline Class & N & Mean & Max & Min \\
\hline Experiment & 30 & 80,2 & 100 & 48 \\
\hline Control & 30 & 70,9 & 96 & 40 \\
\hline
\end{tabular}

From the table above, it can be seen the mean score of experimental class is 80,2 , which is higher than the mean score of controlclass 70.9. Then, maximum score of experimental class is 100 and minimum score is 48 . Whereas the maximum score of control class is 96 and minimum score is 40. It is pointed that students in experimental class have higher score of reading than students in control class.

Furthermore, reading test results in both experimental and control class were analyzed in order to know the normality testing of the data. The result of normality testing is shown in table 4 below: 
Table 4. Normality Testing of Students' Reading Test in Experimental and Control Class

\begin{tabular}{|c|c|c|c|c|}
\hline Class & $\mathbf{N}$ & Lobserved & Ltable & Data Distribution \\
\hline Exp & 30 & 0.0221 & 0.0313 & $\mathrm{~L}_{\text {observed }}<\mathrm{L}_{\text {tablenormal }}$ \\
\hline Control & 30 & 0.0125 & 0.0313 & $\mathrm{~L}_{\text {observed }}<\mathrm{L}_{\text {table }}$ normal \\
\hline
\end{tabular}

Related to the Table 4 above, it can be summarized that all of the students' reading comprehension score in both experimental and control class were normally distributed. It was proven by the value of $\mathrm{L}_{\text {observed }}$ from each group was lower than $\mathrm{L}_{\text {table. }}$.

Then, homogeneity testing was done to see whether the data analysis in both experimenta land control class are homogenous or not. The formula used for testing the homogeneity was Variance Test (F-test) and it was conducted to the data analysis of students' writing.

Table 5. Summary of Homogeneity Testing of Students' Reading Test

\begin{tabular}{|c|c|c|c|}
\hline Data & $\mathbf{F}_{\text {calculated }}$ & $\mathbf{F}_{\text {table }}$ & Conclusion \\
\hline Reading Test & 0.25 & 0.33 & Homogeneous \\
\hline
\end{tabular}

The table of data description above shows that the value of Fcalculated from students' reading test in both classes is 0.25 is lower than Ftable 0.33.It was clear that the data analysis of students' reading test was homogenous.

On the other hand, the statistical from students' reading ability t-test result in experimental and control class is described in the table below:

Table 6. The Result of t-Test Analysis of Reading Test in Experimental and Control Class.

\begin{tabular}{|c|c|c|}
\hline \multirow{2}{*}{ Data } & \multicolumn{2}{|c|}{ Technique } \\
\cline { 2 - 3 } & $\begin{array}{c}\text { Collaborative } \\
\text { Learning technique }\end{array}$ & $\begin{array}{c}\text { Small Group } \\
\text { Discussion }\end{array}$ \\
\hline $\mathrm{N}$ & 30 & 30 \\
\hline $\bar{X}$ & 80,2 & 70,9 \\
\hline $\mathrm{SD}$ & 13,5 & 12,7 \\
\hline $\mathrm{t}_{\text {observed }}$ & \multicolumn{2}{|c|}{5,25} \\
\hline $\mathrm{t}_{\text {table }}$ & \multicolumn{2}{|c|}{0,271} \\
\hline Df & \multicolumn{2}{|c|}{$30+30-2=58$} \\
\hline Conclusion & $\mathrm{t}_{\text {observed }}>\mathrm{t}_{\text {table }}(5,25>0,271)$ \\
\hline
\end{tabular}

From the table of T-test, it can be read if $t_{\text {observed }}>t_{\text {table }}$ means the research hypothesis $\left(\mathrm{H}_{\mathrm{a}}\right)$ is accepted and if $\mathrm{t}_{\text {observed }}<\mathrm{t}_{\text {table }}$ means the null hypothesis $\left(\mathrm{H}_{0}\right)$ is accepted. It can be seen that the $\left(\mathrm{H}_{0}\right)$ is rejected because $t_{\text {observed }}>t_{\text {table }}(5,25>0,271)$. In other words, collaborative learning produced better reading comprehension ability of the students than small group discussion technique.
Furthermore, in this research Collaborative Learning technique used in experimental class provides more opportunities for students to develop their reading comprehension. This strategy is also activating background knowledge and to check understanding after studying a general topic. Thus, Collaborative Learning technique produces higher result in reading comprehension than small group discussion strategy.

\section{CONCLUSIONS}

The result of this research shows that collaborative learning strategy can be selected as an alternative technique that can be used in teaching reading. This strategy produces better reading ability of the students than small group discussion technique. This strategy provides more opportunities for students to develop their reading ability. Furthermore, collaborative learning strategy encourages the students to share their ideas in group and give correction toward their friends' reading and it will result improvement of their reading skill.

\section{SUGGESTION}

Based on the conclusion above, there are some suggestions that can be given. The teachers are suggested to upgrade their knowledgeabout collaborative learning technique to increase their teaching quality and use this technique in teaching reading. Furthermore, it is suggested for the teachers to use collaborative learning as a technique in teaching English, especially reading. Perhaps, it is useful to see whether this technique brings beneficial impact to different kind of students and different kind of English skills.

\section{REFERENCES}

[1] Blass, Laurie. 2007. Skills and Strategies for Reading. Oxford: Oxford University Press

[2] Bruffee, K. A. (1993). Collaborative Learning: Higher education, interdependence, and the authority of knowledge. Baltimore, MD: Johns Hopkins University Press.

[3] Gokhale, A.A. (1995). Collaborative Learning Enhances Critical Thinking. Journal of Technology education. 7(1).

[4] Hancock, O.H. 1998. Reading skills for college students (4th ed.). Upper Saddle Rivers, NJ: Prentice Hall.

[5] Laal, Marjan \& Seyed Mohammad Ghodsi. (2012). Benefits Of Collaborative Learning. Procedia - Social and Behavioral Sciences 31 (2012) 486 - 490. 
[6] Martin-Chang, S.Y., \& Gould, O.N. (2008). Revisiting print exposure: Exploring differential links to vocabulary, comprehension and reading rate. Journal of Research in Reading, 31, 273284.

[7] Pressley, M. 2000. What Should the Comprehension Instruction be instruction of? In M. Kamil, P. Mosenthal, P. Pearson \& R. Barr (Eds.), Handbook of reading research (Vol. 3, pp. 269-284). Mahwah, NJ: Lawrence Erlbaum.

[8] Roselli, N. (2016). Collaborative Learning: Theoretical Foundations and Applicable Strategies to University. Propositos y Representaciones, Vol. 4, 219-280.

[9] Wegmann, B., Knezevic, M.P., and Bernstein, M., 1985. Mosaic II: Reading Skills Book. New York: Random House, Inc. 